\title{
The Decline of Creative Education in the City of Rio de Janeiro: Main Causes and Consequences
}

\author{
Diego Santos Vieira de Jesus, Daniel Kamlot, Veranise Jacubowski Correia Dubeux \\ ESPM-Rio, Rio de Janeiro, Brazil \\ Email: dvieira@espm.br, danielkamlot@yahoo.com.br, veranise.dubeux@gmail.com
}

How to cite this paper: de Jesus, D. S. V., Kamlot, D., \& Dubeux, V. J. C. (2019). The Decline of Creative Education in the City of Rio de Janeiro: Main Causes and Consequences. Creative Education, 10, 1670-1684. https://doi.org/10.4236/ce.2019.107119

Received: June 20, 2019

Accepted: July 26, 2019

Published: July 29, 2019

Copyright $\odot 2019$ by author(s) and Scientific Research Publishing Inc. This work is licensed under the Creative Commons Attribution International License (CC BY 4.0).

http://creativecommons.org/licenses/by/4.0/

(c) (i) Open Access

\begin{abstract}
The aim is to examine the main causes and consequences of the decline of creative education in the city of Rio de Janeiro. The main argument indicates that the decline is related not only to the technical difficulties regarding the stimulation of interdisciplinarity and transversality of the acquired knowledge, the connection between artistic and critical abilities and the incorporation of contents linked to creative competencies into its current educational programs. The city also suffers from the reduction of government and private investment in innovation, as well as the negative impacts of economic crises and political problems, especially corruption and the discontinuity of public policies.
\end{abstract}

\section{Keywords}

Creative Education, Rio de Janeiro, Economic Crisis, Technical Difficulties, Corruption

\section{Introduction}

In the 1980s, the concept of "creative city" was predominantly used in reference to a place where artists played a central role and the imagination and creativity established the "urban spirit". Creative industries-from design to performing arts-have had great importance over time because of their economic relevance and role in creating an urban identity. Gradually, the presence of a large "creative class" (Florida, 2002) as well as research communities and nomads of knowledge indicated the existence of a "creative city". Nowadays, the concept of "creative city" refers more commonly to urban spaces where the efficient articulation between social and artistic activities, cultural industries and government was able to produce a cultural effervescence that develops and attracts talents, promotes social diversity, increases the job offer, generates greater knowledge among 
citizens, increases the creative potential of companies and institutions, attracts more tourists and thus contributes significantly to the city's economy and the quality of life of its citizens. According to Landry (2011), the creativity of a city can be applied to multiple fields that transcended the creative industries or the presence of a creative class: for a creative class to flourish, public administration should promote social innovations with creativity in areas such as governance, health, public security and education.

In its turn, education is important for the development of a creative city because it promotes the development of creative and innovative skills necessary for a better governance, as well as the promotion of the life quality of its citizens. Creative education is based on a multidisciplinary perspective and encompasses sensitivity, entrepreneurial attitudes, social and communication skills, understanding of sociocultural dynamics and market and political analysis (Hearn \& Bridgstock, 2010). Although education is fundamental for the consolidation of a creative city, some urban spaces that were classified this way-especially in the developing world-see the rapid decline of their educational systems (Jesus \& Kamlot, 2018).

Rio de Janeiro is one of the cities around the world which sees the rapid decline of the educational system, necessary for the consolidation of its position as a creative city. The main purpose of this article is to examine the main causes and consequences of the decline of creative education in that city. The main argument indicates that the decline is related not only to the technical difficulties regarding the stimulation of interdisciplinarity and transversality of the acquired knowledge, the connection between artistic and critical abilities and the incorporation of contents linked to creative competencies into its current educational programs. The city also suffers from the reduction of government and private investment in innovation, as well as the negative impacts of economic crises-which make investment and the access to education by the population more difficult-and political problems, especially corruption-which deviates resources that should be used in schools and universities for the maintenance of infrastructure and the payment of salaries of education professionals-and the discontinuity of public policies.

\section{Theoretical Framework}

The literature shows that the emergence of "creative industries"- such as crafts, fashion, audio-visual, music, book and the new software and games industries (Miguez, 2007) - is very connected to the transformation from materialistic to post-materialistic values and the attendance of aesthetic and intellectual needs of people and their involvement in autonomous decision-making processes. This took place in the context of the fourth Industrial Revolution and the consolidation of the knowledge society, in which capital is based on intellectual resources (Bendassolli et al., 2009; Jesus \& Kamlot, 2017). In the light of these changes, the qualification of creative professionals in the use of technologies was needed to 
respond to the increasing market demands. Instead of the preparation of a standardized labor force as in industrial economy, the knowledge society needs to prepare a more flexible one for the creative economy, with an education process which also includes business practices and critical political and social thought (Florida, 2002, 2005). In this sense, the interdisciplinarity between arts, humanities and sciences and the independent thinking need to be developed from the earliest stages of the educational process to the university to promote more independent actions, creative and imaginative engagement and research skills by students for the production of innovation (Araya, 2010; Venturelli, 2000).

The technical/scientific and cultural/creative pillars of creative education allow the insertion of new topics of knowledge, while the business pillar turns them into products and services valued by the market and society (Hearn \& Bridgstock, 2010). The interconnectedness goes side by side with the notion that collaboration on various platforms may lead to learning and innovation based on collective intelligence networks that stimulate cooperation and innovation (Araya, 2010). This education also encompasses the development of critical thinking about the political-economic and socio-cultural dynamics, especially those involving issues such as sustainability and the respect for cultural differences based on origin, ethnicity, gender, sexual orientation and economic situation. Creative education includes the valuation of traditional knowledge and practices in order to stimulate students to think critically about past problems and imagine possible solutions for the future. The education for the preservation of cultural heritage, for example, is fundamental to the development of a creative city, insofar as it can enable the restructuring of urban spaces emphasizing the arts, differentiated services and entertainment to attract creative professionals; reappropriate, restore and rehabilitate the present, aiming at a future of renewed social relations in the city; and lead to the apprehension of traditional knowledge, transversal to several fields, aiming at socioeconomic development (Tomaz, 2010).

Nevertheless, creative cities in the developing world, especially in Brazil, show some limitations in the development of creative education. Interdisciplinarity and transversality of the acquired knowledge by students are rarely stimulated in the light of the rigidness of curriculum guidelines. The development of artistic, creative and critical abilities and the investment in disruptive and incremental innovation are commonly replaced by the transmission of acritical knowledge for students, which preserves the logic of an industrial system based on the stimulus of technical competences which marginalize creativity for the promotion of innovation in processes, products and services in social, economic and political organizations, as well as critical notions of citizenship. There are also problems related to economic crises, responsible for limiting the resources available for education and the construction of partnerships between the government and the private sector, which can bring alternatives for funding activities in hard economic times. It is also possible to cite the political issues associated to the corruption and the misuse of funds for education by politicians and business- 
men (Jesus \& Dubeux, 2018). These problems limit the possibilities to develop innovation, which is fundamental to stimulate economy recovery and create job and income opportunities (Li, 2013). The development of creative competencies into current educational programs, the encouragement of the interaction between technical schools and social initiatives and the strengthening of incubators and research centers would have an essential role in the process of recovery during crises, but these initiatives face obstacles related to limitation of resources, political discontinuities and corrupt schemes and the preservation of a technical approach devoted to the necessities of a traditional society, not an innovative one (Jesus et al., 2018).

\section{Methodology}

The bibliographic research consisted of reading, selecting and organizing topics on the decline of creative education in the city of Rio de Janeiro. The next steps were the research of the political, economic and technical contexts that motivated the crisis of creative education in the city of Rio de Janeiro and the evaluation of how the obstacles for the full potential of creative education as an engine for development were created and consolidated. At this step, we used information released by governmental institutions and statements and data from government officials and education institutions' managers, drawn from the media and think tanks, as well as the official websites of basic, secondary and higher education institutions in the city. In the proposed content analysis, the collected data were organized into four categories: 1) the political crisis of Rio de Janeiro and its effects on education; 2) the economic crisis of Rio de Janeiro and its effects on education; 3) the technical crisis of education in the city of Rio de Janeiro; 4) the consequences of the decline of creative education in Rio de Janeiro.

\section{Results and Analysis}

In the 2000s and the early 2010s, Rio de Janeiro started to develop the image of a "creative city" as a mechanism for urban transformation, social inclusion, development of cultural capital and the construction of an international showcase for attracting business and talent. With the support from the federal and state governments, the city administration articulated with creative industries and cultural producers to establish a space for the valuation of diversity and entrepreneurship. To stimulate cultural capital, the municipal government sought to broaden the network of public cultural spaces, strengthen access to culture and, specifically, focus on supporting production, marketing, infrastructure and training for creative sectors. The dissemination of the image of the city abroad was based on the realization of huge sociocultural events, such as the parades of samba schools during Carnival season, and mega sport events, such as the 2016 Olympic and Paralympic Games (Aprigio, 2015). These initiatives could also stimulate tourism, as well as preserve the cultural heritage and the environment to the benefit of local population. 
However, Rio de Janeiro was affected by multiple crises, and some of them resulted from problems in the education area or had impacts in this sector. The main crises Rio de Janeiro has been through and their effects on creative education are presented in Table 1.

\subsection{The Political Crisis of the City of Rio de Janeiro and Its Effects on Education}

According to Bezerra (2012), corruption is structured in the public apparatus in Brazil through the creation of personal networks and can be defined by relations and practices that protect specific groups and elites, as evidenced in cases of corruption in which politicians from all over the country have been involvedsince Brazil was a Portuguese possession-in the national, federation state and municipal public spheres. The worsening of the political crisis relates to the complexification of these personal networks, which have become public more frequently since the beginning of this decade due to the greater performance of the Federal Police in investigating such cases, the greater action of the Judiciary in the punishment of politicians and businessmen involved in corruption cases and greater information brought by the media about corruption. The gradual dismantling of corruption networks has affected numerous actors involved in such schemes and brought fear to potential investors, who reallocated their resources for other

Table 1. Crises of the city of Rio de Janeiro and their effects on creative education.

\begin{tabular}{|c|c|}
\hline Crises & Effects on creative education \\
\hline \multirow{4}{*}{ Political } & 1) Corruption limits resources for creative education. \\
\hline & 2) Political instability and clashes of interests among politicians compromise the \\
\hline & continuity of policies dedicated to the promotion of creative education. \\
\hline & 3) Access to schools and universities became more difficult with crime and violence. \\
\hline \multirow{7}{*}{ Economic } & 1) The imbalance of public accounts undermined Brazilian credibility and limited the \\
\hline & amount of money to invest in strategic sectors, such as education. \\
\hline & 2) The economic recession-coupled with the slowdown in the activities of the oil \\
\hline & industry and the fall in tax revenues in the state of Rio de Janeiro-led to a greater \\
\hline & pauperization of the population. Many students are not able to complete their \\
\hline & educational formation because they must enter the job market earlier, in subaltern \\
\hline & positions. \\
\hline \multirow{15}{*}{ Technical } & 1) The educational infrastructure does not deal effectively with interdisciplinarity and \\
\hline & transversality of knowledge nor bring ways to promote them in schools or how to \\
\hline & strategically develop transdisciplinarity among cultural, technological and entrepreneur \\
\hline & areas since the earliest stages of the educational process. \\
\hline & 2) In many private institutions of basic and secondary education in Rio de Janeiro, the \\
\hline & focus is still in the preparation of the students for the entrance exam in universities, \\
\hline & with a scarce preoccupation with the stimulus to artistic or creative competences, as \\
\hline & well as a more critical view on the deep social issues in Brazilian society. \\
\hline & 3) In public higher education institutions, a sharp cut in resources occurred in recent \\
\hline & years and was accentuated in 2019 , including the ones located in Rio de Janeiro. \\
\hline & Because of reduced funds, it is more difficult to produce scientific research with signif- \\
\hline & icant impact on public management and the productive system. \\
\hline & 4) The cuts of resources in agencies that contribute to the development of science and \\
\hline & knowledge in Brazil affected private higher education institutions, including some \\
\hline & located in Rio de Janeiro. \\
\hline
\end{tabular}


countries (Jesus, 2019). With less resources, the chances for investment in creative education were limited, including in Rio de Janeiro.

More recently, there was the gradual dismantling of corruption schemes spread throughout the political apparatus of the state of Rio de Janeiro, including its capital, but it was not enough to recover the lost investments in many strategic sectors of Rio de Janeiro's society, including education. Two governors-Sérgio Cabral Filho and Luiz Fernando Pezão-were arrested in the context of Lava Jato Operation, a set of investigations underway by Brazilian Federal Police, which began in March 2014. The operation investigates crimes of active and passive corruption, fraudulent management, criminal organization and obstruction of justice in Brazil. The Lava Jato Operation brought new accusations and arrests in Rio de Janeiro during 2018 and 2019. From its beginning to October 2018, 190 people were arrested, 39 people were arrested temporarily, 40 coercive conducts occurred, and 466 searches and seizures were implemented, according to the Federal Public Ministry (MPF, its acronym in Portuguese). The crimes involved active and passive corruption, money laundering, criminal organization, gang formation, ideological falsehood, currency evasion, crime against the economic order and the financial system, influence peddling, operation of unauthorized financial institution and embezzlement, among others (MPF, 2018).

In the city of Rio de Janeiro, an impeachment request process was open against Mayor Marcelo Crivella in April 2019, because he would have extended, without legal permission, a 1999 concession authorizing two groups of advertising agencies to use 34 public places such as bus stops and street clocks for advertising. The contract provided for the operation of these sites for 20 years and had no clause permitting renewal. Previously, other impeachment requests from the mayor had been denied (Barreira et al., 2019). With the political instability, the continuity of many policies dedicated to the promotion of creative education was compromised, and new proposals were not implemented nor were able to work in the light of the clashes of interests among politicians and the establishment of other priorities by them, such as the maintenance of their political offices.

The unfavourable economic and political situation led to the spread of crime in the state of Rio de Janeiro and its capital throughout 2018, so even the access to schools and universities became more difficult in the light of the dispute between the Police and the criminals. Three months before the end of the federal intervention in the security of the state of Rio de Janeiro-which started in January 2018-it was possible to detect the fall in certain types of robberies and thefts, but the number of homicides had increased (4039 violent deaths between February and August 2018, in comparison with 3810 in the same period in 2017), with a quarter of them being caused by police officers. Between February and August 2018, 82,578 thefts were registered, while 84,400 were registered in the same period in 2017. There was an increase in certain types of robberies, such as those against passengers in collective transportation. Although there was 
a reduction of $9.5 \%$ in cargo theft in the state, this reduction came to the cost of $\mathrm{R} \$ 46$ million (US\$12 million) in operations of the Armed Forces. This last reduction results from the concentration of resources in this issue to meet the demands of entrepreneurs, but crimes against life continued to increase. Although there was a slight decrease in the number of police officers' deaths, 916 people were killed between February and August 2018 by police interventions, a number that exceeded 615 deaths in the same period of 2017. The federal intervention tested a model of public security based on a military conception, which thought violence and crime as war problems, not from changes in management, strengthening of intelligence and reduction of crimes against life (Fábio, 2018). In the light of the danger brought by violence and crime, mobile applications were created to indicate locations where shootings and other crimes occur, and these statements are reported by the users themselves, who send alerts to the other individuals who are users of the software.

The social participation practices in the formulation of public policies in the city of Rio de Janeiro could be more stimulated if there were a greater investment in creative and critical education. However, an example that these practices have been threatened in the city was visible in the murder of the councilor Marielle Franco and her driver Anderson Gomes, in the neighbourhood of Estácio, in March 2018. As a defender of the rights of women, the LGBT population, blacks and the population of the city's favelas, Franco was the fifth most voted candidate for the position in the city in 2016 and the second most voted councilwoman in the entire country. In the city government, she was part of a commission which had the objective of monitoring the federal intervention in Rio de Janeiro's public security and was chosen as the commission's rapporteur in February 2018. Franco was very critical of federal intervention, police abuses and human rights violations (Odilla, 2018).

\subsection{The Economic Crisis of the City of Rio de Janeiro and Its Effects on Education}

The economic crisis of Rio de Janeiro reflects, in part, a national problem. In the light of the fall in the price of commodities of which Brazil remains extremely dependent, policies to encourage consumption continued in force by Brazilian government, but the side effect of this was an imbalance of public accounts, which undermined Brazilian credibility and limited the amount of money to invest in strategic sectors, such as education (Jesus \& Kamlot, 2017). Because of this limitation, the funding of projects devoted to the development of artistic and critical abilities in students and innovation-which would benefit not only companies, but the society in general-were reduced or interrupted. In the state of Rio de Janeiro, the economic recession-coupled with the slowdown in the activities of the oil industry and the fall in tax revenues-led to a greater pauperization of the population, which was further exacerbated by the corruption spread by the political apparatus, described above. The situation has led not only to a shortage of state officers' salaries, but the collapse of state government pro- 
grams in 2017 and 2018. The chaotic situation of Rio de Janeiro-especially in its capital-not only complicates the access of students to schools because of the violence in many communities. Many of these students are not able to complete their educational formation because they must enter the job market earlier, in subaltern positions, or even see better opportunities of life working for drug cartels in the favelas.

Creative education is also important to stimulate local vocations, but the industries and service providers in the city remained weakened during the political-economic crisis, which created a discouragement of the city's vocations. Among the factors that reflect this crisis, it is worth mentioning the worsening of unemployment, the main cause of defaults in Rio de Janeiro's commerce in 2018. More than half of the cases of defaults (55\%) were due to unemployment, followed by a decrease in income (20\%), delays in payment (10\%) and lack of control of expenses (8\%), among other factors (Lucena, 2018). The worsening of the unemployment situation in the city and the state of Rio de Janeiro is deeply related to the fiscal crisis, which has lasted for at least three years. The situation resulted from policies applied to solve the tax issues, which, instead of focusing on tax reforms, chose to freeze public investments for two decades and sell the national assets, such as the oil reserves in the pre-salt layer. In 2018, the president of the National Deputies' Chamber, Rodrigo Maia, approved the tax recovery agreement of Rio de Janeiro, so that the federal state would make adjustments of R $\$ 63$ billion (US\$12 billion) by 2020 , with measures that included the cut of expenses in the first four months of 2018. 3642 jobs were lost in the state, a situation mainly driven by the commerce sector (Gonçalves, 2018). The fiscal crisis also affected the consumption of families due to delays in the payment of salaries of active civil servants, retirees and pensioners, which began in early 2016, and payments began to be settled only in early 2018. This crisis has created obstacles to access to private schools and universities that could promote creative education. It has also aggravated the bad indicators of public safety, which interferes with trade, tourism and education, as shown above. It should be noted that a large part of the fiscal problem is related to the Petrobras crisis, affected by the Lava Jato investigations (Estadão, 2018).

In the specific case of the city of Rio de Janeiro and the metropolitan region of the state, the non-preservation of the legacy of the 2016 Olympic Games and the fiscal crisis made this metropolitan region the Brazilian champion in the closing of job opportunities, with a total number of 38,400 people fired between June 2017 and June 2018. The crisis in Rio de Janeiro-particularly in the state capital-eventually created obstacles to the Brazilian recovery. After the Olympic Games and layoffs in the construction sector, the state of Rio de Janeiro had the country's sixth highest unemployment rate in the second quarter of 2018 (15.4\%). The state's fiscal crisis had affected the expectations of the business community, which reduced the possibility of hiring (Estadão, 2018). Prospects for recovery in business and employment remained low in the first quarter of 2019 due to a series of difficulties. In the case of industry, the recovery move- 
ment had to overcome the operational limitation related to the large idle capacity in the production lines. Without the investments in the existing operations or the opening of new units in 2019, the tendency is the deterioration of the scenario in the labour market. In addition, the non-approval of the Pension Reform creates obstacles to recovery, especially in Rio de Janeiro, where the crisis has reached monumental proportions. Without such reforms, companies may leave the country, and the currency can lose strength with higher inflation. With interest increases, the debt increases, and the credit lacks (Teixeira, 2019).

\subsection{The Technical Crisis of Education in the City of Rio de Janeiro}

According to the National Education Plan, the educational systems in Brazil must support knowledge and learning in continuous cultural innovation, but the same plan recognizes that it was still based in an industrial model and focused on a reproductive logic. The educational infrastructure does not deal effectively with interdisciplinarity and transversality of knowledge nor bring ways to promote them in schools or how to strategically develop transdisciplinarity among cultural, technological and entrepreneur areas since the earliest stages of the educational process (Jesus \& Dubeux, 2018). The difficulties of ownership due to cost and regulatory problems regarding new technologies are related to a gap in the stimulation of the students' technological skills and the valuation of students' creative thinking in the teaching process (Reis, 2008). The 2017 School Census by the Ministry of Education shows that the presence of technological resources such as computer labs and internet access still does not happen in many Brazilian schools. Only $46.8 \%$ of primary schools have a computer lab; $65.6 \%$ of schools have access to the internet; in $53.5 \%$ of schools, the internet is broadband. The state of Rio de Janeiro is one of the places in Brazil with the highest number of public schools. However, between 2014 and 2015, this state had a 72\% drop in investment in infrastructure and maintenance. The city of Rio de Janeiro has more than 1000 municipal schools, but a 2011 survey conducted by the Municipal Department of Education found out that $62 \%$ of the municipal school infrastructure was "poor or bad" (Longaigh, 2017).

In many private institutions of basic and secondary education in Rio de Janeiro, the focus is still in the preparation of the students for the entrance exam in universities, with a scarce preoccupation with the stimulus to artistic or creative competences, as well as a more critical view on the deep social issues in Brazilian society. Although some private schools develop a model of creative education compatible with international standards regarding academic excellence, life intelligence and global citizenship, they must adapt their creative proposals to rigid curricular guidelines and charge high monthly fees to maintain their infrastructure and services, which is not affordable for the greatest part of Rio de Janeiro's population.

In Brazilian public higher education institutions, a sharp cut in resources occurred in recent years and was accentuated in 2019, including the ones located in 
Rio de Janeiro. Because of reduced funds, there is more difficulty to produce scientific research with significant impact on the public management and the productive system. While some developed countries allocate up to 5\% of GDP for innovation, the 2018 budget for innovation in technology, science and innovation in Brazil was the lowest in the decade (Soares, 2018). The cuts deeply affect agencies that support research and infrastructure projects for researchers and teaching and research institutions. In May 2019, the Brazilian government cut funds for basic activities in federal universities all over the country, as well as resources of agencies that contribute to the development of science and knowledge in Brazil, such as the Brazilian National Council for Scientific and Technological Development (CNPq, its acronym in Portuguese). Some institutions such as the Federal University of Rio de Janeiro (UFRJ, its acronym in Portuguese) were one of the most affected by the cuts. It is also important to say that the revelation by Lava Jato Operation that companies were involved in cases of corruption compromised the allocation of funds for innovation. The generalized crisis affected the employment and reflected the greater economic instability and risk associated with existing businesses, as well as damaged the generation of new ventures and limits the creation of jobs. Multiple innovation projects in public universities that depended on the government support lacked funds or were terminated. Many internationally renowned research groups were dismantled, and the "brain drain" to other countries became more intense, which can seriously compromise Brazilian future regarding the promotion of innovation (Lewer, 2017).

The cuts of resources in agencies that contribute to the development of science and knowledge in Brazil also affected private institutions, including institutions located in Rio de Janeiro, such as the Pontifical Catholic University of Rio de Janeiro (PUC-Rio, its acronym in Portuguese). Besides, many private universities suffer from the limitation of student financing programs. As the number of unemployed people is high and salaries are low, students are less able to afford the tuition fees of a higher education institution. Such students have a hierarchy of priorities in their expenses, and basic ones such as rent and food are in a higher position than education. To cut costs, students end up not entering universities or choose to abandon them because of their reduced income (Jesus, 2019).

\subsection{The Consequences of the Decline of Creative Education in Rio de Janeiro}

The population of Rio de Janeiro, in recent times, has been showing increasing dissatisfaction with the city. More than $70 \%$ of the cariocas indicated some degree of displeasure with the city, a number similar to those that showed interest in moving to another city (Veja Rio, 2016). In the opinion of the residents, items such as lack of security, chaotic traffic, pollution and lack of good care would be responsible for the feeling of abandonment and the reduction of self-esteem. In 2019, some projects developed by the city council began to be put into practice, which apparently helped in an improvement in the confidence of the inhabi- 
tants. The Confidence Index of the Fluminense (inhabitant of the state of Rio de Janeiro) Industrial Managers, that ranges from 0 to 100 points-with points above 50 indicating optimism and below that value, pessimism-reached 60.4 points in January 2019, which represents 10.2 points above the historical average of the index, being the first time since 2011 that the local industry begins the year with high optimism, which can be credited, in part, to the results of the capital city of Rio de Janeiro. Also, the indicator of expectations for the next six months reached 66.0 points, against a historical average of 54.2 points, that is, an increase of 11.8 points (Silveira, 2019).

Despite all the difficulties faced by the city in the social, economic and environmental spheres, the city of Rio de Janeiro was recognized by UNESCOUnited Nations Educational, Scientific and Cultural Organization-as the First World Capital of Architecture. The carioca architectural group surpassed cities like Melbourne and Paris, and its recognition was declared based on works such as the Museum of Modern Art, the Royal Portuguese Reading Office, the Municipal Theater, the Lage Park, the Monastery of São Bento, the City of the Arts and the Museum of Tomorrow, among others (Camargo, 2019). However, some of the most visible expressions of the decline of creative education in Rio de Janeiro are the neglect and depredation of the material heritage and the devaluation of the immaterial heritage, which show the lack of an intense patrimonial education process (Tomaz, 2010). The poor conditions of preservation of the cultural heritage in Rio de Janeiro-which highlights the lack of investment of the government in maintenance and conservation of cultural spaces and their prioritization in public policies-were evident in the fire of great proportions that reached the National Museum, in September 2018, which is managed by UFRJ. The fire was considered the worst tragedy involving Brazilian cultural and scientific heritage. In April 2019, the Federal Police stated that the fire that destroyed the museum began in one of the air conditioners in the ground floor auditorium of the three-story building (Silveira, 2019).

The decline of creative education in Rio de Janeiro was also visible when education and culture seemed to be two opposite universes by the city administration. For example, the mayor Crivella said that, because of the economic and financial crises in the city and the necessity to develop new schools, he cut resources from some the most important cultural events of the city, such as Carnival. In March 2019, Crivellastated that Rio de Janeiro was an "epicenter of corruption and violence" and that it would only be possible to overcome such crisis with "behaviour changes" so that the political leaders of the city would no longer have a "carnival look" of public office. According to Crivella, he withdrew public funds from Carnival, but sought to ensure that the resources for the event came from the private sector. According to him, public men should "like simple things and give value to solidarity, humility, confidence and austerity". Many society groups indicated that Crivella took this decision based on his religious motivations and created a dichotomy between education and culture, as if one did not feed the other (Nogueira, 2019). 
The lack of creative education compatible with the notion of sustainable development still puts Rio de Janeiro in a very low position in the Sustainable Cities Index. In the 2017 index, Rio de Janeiro occupies the 82nd position, behind cities such as Beijing (73rd), São Paulo (79th) and Buenos Aires (80th) (Arcadis, 2017). This index is calculated based on a broad measure of sustainability, encompassing social, environmental, and economic indicators of cities. Social health measurement reflects social mobility and the quality of opportunities and life; environmental measurement is based on the management of energy use, pollution and other emissions; and economic measurement assesses the business environment and economic performance (Arcadis, 2018). In 2018, Rio de Janeiro came to occupy the 84th position, falling two positions when compared to the previous ranking - which denotes the need for improvement in the measures in question. Analyzing each of them, Rio ranks 90th in the social health index, 47th in the environmental index, and 93rd in the economic index. For the sake of comparison, São Paulo (the largest Brazilian city) now occupies the 78th position, Beijing is the 73rd, and Buenos Aires, the 81st. It is noticeable that there are issues to be improved in Rio de Janeiro, especially in the social and economic spheres, which impact in education. The reputation of the city suffers from the consequences of the problems in the promotion of creative education, although not all of its problems may be justified by this decline. For example, in the 2018 Cities in Motion Index, the city occupies the 126th position, dropping 12 positions compared to 2017 (114th) (IESE, 2018). This last index remained below the minimum desirable. In 2018, the worst indexes are urban mobility, governance and human capital. In the 2018 City RepTrak, the city occupies the 51st. position and continues in the list of the "Bottom 10 Cities", the ten cities considered in the report with the worst reputations.

\section{Final Considerations}

The decline of creative education in the city of Rio de Janeiro is only "the tip of the iceberg" of more structural problems. To overcome this situation, it would be necessary, in the economic dimension, to seek the fiscal adjustment of the state of Rio de Janeiro, present in the fiscal recovery project, in order to reduce its expenses so that it gradually returns to offer quality public services, in addition to maintaining the payment of state public officers (Gonçalves, 2018). It would not only guarantee the consumption capacity of these professionals and stimulate the attraction of investments-which is linked to the development of competitiveness-but would give people the opportunity to keep studying. It is also important to stimulate the Social Security Reform to stimulate the resumption of investments in the city and the state of Rio de Janeiro, as well as invest in the engagement with the business and the third sectors in the training of citizens for the engagement of such people in productive sectors related to urban vocations, with the use of local knowledge in the generation of income and employment. 
In the light of the deficiencies of public security policy in Rio de Janeiro-still characterized by the high level of lethality in police actions-and the non-recognition of an efficient public administration, creative education is necessary to stimulate the engagement of organized groups in civil society in the formulation of municipal public policies and the monitoring of political actions and expenses of city, state and federal authorities aiming at public transparency. Education is also necessary to exert pressure on public administration to reduce police lethality and stimulate the professionalization of the police force, as well as changes in the management of public security with the focus on the strengthening of intelligence and the reduction of crimes against life (Fábio, 2018).

A reformulation of creative education in Rio de Janeiro would have to take into consideration the development of initiatives devoted to heritage preservation and the stimulus of a stronger connection between innovation and life quality, as well as the divulgation of Rio de Janeiro's image based on the sociocultural events that take place in the city. For these initiatives to work, it would be necessary to incorporate even more, in the creative education initiatives, the notion of diversity as one of the main aspects connected to the identity of the city to stimulate the feeling of belonging of individuals to the place. This means the respect to the plurality of their cultural and artistic manifestations and the guarantee of expression of all differences, including the ones related to race, origin, gender and sexual orientation.

Another issue to be considered is the vocation for innovation actions found in Rio inhabitants. Innovation can be a facilitator for long-term development, which would sustain the well-being of a metropolis such as this one. Efficient, creativity-based policies would be useful, with a view to reaching economically sustainable development and educational resources.

\section{Conflicts of Interest}

The authors declare no conflicts of interest regarding the publication of this paper.

\section{References}

Aprigio, A. E. R. S. (2015). A paradiplomacia e a atuação internacional de governos subnacionais. M.A. Dissertation in International Relations, Departamento de Relações Internacionais e Administração Pública, Escola de Economia e Gestão, Amarante: Universidade do Minho.

Araya, D. (2010). Educational Policy in the Creative Economy. In D. Araya, \& M. A. Peters (Eds.), Education in the Creative Economy: Knowledge and Learning in the Age of Innovation (pp. 3-28). New York: Peter Lang Publishing Inc.

Arcadis (2017). Sustainable Cities Index, 2017.

https://www.arcadis.com/en/global/our-perspectives/sustainable-cities-mobility-index$\underline{2017 /}$

Arcadis (2018). Sustainable Cities Index, 2018.

https://www.arcadis.com/en/global/our-perspectives/sustainable-cities-index-2018/citi zen-centric-cities 
Barreira, G., Maria, E., Duarte, H., Figueiredo, P., \& Abreu, R. (2019). Câmara do Rio abre processo de impeachment contra o prefeito Marcelo Crivella.

https://g1.globo.com/rj/rio-de-janeiro/noticia/2019/04/02/camara-do-rio-abre-process o-de-impeachment-contra-o-prefeito-marcelo-crivella.ghtml

Bendassolli, P. F., Wood Jr., T., Kirschbaum, C., \& Cunha, M. P. (2009). Indústrias criativas: Definição, limites e possibilidades. $R A E$, 49, 10-18.

https://doi.org/10.1590/S0034-75902009000100003

Bezerra, M. O. (2012). Estado, representação política e corrupção: Um olhar antropológico sobre a formação de fronteiras sociais. Crítica e Sociedade: Revista de cultura política, 2, 2.

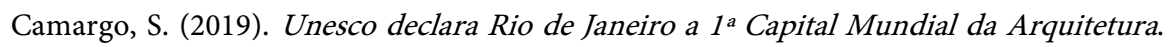
Conexão Planeta, 18 jan. 2019.

http://conexaoplaneta.com.br/blog/unesco-declara-rio-de-janeiro-a-1a-capital-mundia 1-da-arquitetura

Estadão (2018). Região Metropolitana do Rio lidera fechamento de vagas em 12 meses. https://www.em.com.br/app/noticia/economia/2018/08/21/internas_economia,982242/ regiao-metropolitana-do-rio-lidera-fechamento-de-vagas-em-12-meses.shtml

Fábio, A. C. (2018). Os números da violência no Rio, a 3 meses do fim da intervenção. https://www.nexojornal.com.br/expresso/2018/09/19/Os-n\%C3\%BAmeros-da-viol\%C3 \%AAncia-no-Rio-a-3-meses-do-fim-da-interven\%C3\%A7\%C3\%A3o

Florida, R. (2002). The Rise of the Creative Class and How It's Transforming Work, Leisure, Community and Everyday Life. New York: Basic Books.

Florida, R. (2005). The Flight of the Creative Class: The New Global Competition for Talent. New York: Harper Collins. https://doi.org/10.4324/9780203997673

Gonçalves, J. (2018). Crise fiscal agrava desemprego no Rio de Janeiro. https://odiariocarioca.com/noticia-2018-06-12-crise-fiscal-agrava-desemprego-no-riode-janeiro-9619151.carioca.html

Hearn, G. N., \& Bridgstock, R. S. (2010). Education for the Creative Economy: Innovation, Transdisciplinarity, and Networks. In D. Araya, \& M. A. Peters (Eds.), Education in the Creative Economy: Knowledge and Learning in the Age of Innovation (pp. 93-116). New York: Peter Lang Publishing Inc.

IESE (2018). IESE Cities in Motion Index 2018. https://citiesinmotion.iese.edu/INDICECIM/?LANG=EN

Jesus, D. S. V. (2019). When Creativity Dies: Creative Economy in Brazil's 2018 Presidential Election. International Journal of Development Research, 9, 26335-26339.

Jesus, D. S. V., \& Kamlot, D. (2017). Stuck in the Middle of Nowhere: Cultural Policy, Development and Creative Industries in Brazil. Creative Industries Journal, 10, 139-154. https://doi.org/10.1080/17510694.2017.1318255

Jesus, D. S. V., \& Kamlot, D. (2018). The Education for Creative Economy in Brazil: Opportunities and Challenges. Journal of Modern Education Review, 8, 268-273.

Jesus, D. S. V., \& Dubeux, V. C. J. (2018). The Crisis in Private Higher Education in Brazil: Main Causes and Possible Solutions. International Journal for Innovation Education and Research, 6, 35-46.

Jesus, D. S. V., Kamlot, D., \& Dubeux, V. C. J. (2018). Technology, Culture and Citizenship in Education for Creative Economy in Brazil: The Case of the NAVE Project in Rio de Janeiro. International Journal of Advanced Engineering Research and Science, 5, 91-100. https://doi.org/10.22161/ijaers.5.9.10

Landry, C. (2011). Prefácio. In A. C. F. Reis, \& P. Kageyama (Eds.), Cidades criativas: Perspectivas (pp. 7-15). São Paulo: Garimpo de Soluções. 
Lewer, L. (2017). Ganhadores de Nobel pedem que Temer interrompa cortes na ciência. http://www1.folha.uol.com.br/ciencia/2017/09/1923338-ganhadores-de-nobel-pedem-q ue-temer-interrompa-cortes-na-ciencia.shtml

Li, W. W. (2013). The 12th Five-Year Plan and the Transformation of Economic Development from the Perspectives of Creative Industries. International Journal of Cultural and Creative Industries, 1, 66-92.

Longaigh, C. N. (2017). Uma introdução à educação pública no Rio de Janeiro. http://rioonwatch.org.br/?p=24544\%20;\%20https://racismoambiental.net.br/2017/02/1 8/uma-introducao-a-educacao-publica-no-rio-de-janeiro

Lucena, F. (2018). Desemprego foi a principal causa da inadimplência no comércio do Rio de Janeiro.

https://diariodorio.com/desemprego-foi-a-principal-causa-da-inadimplencia-no-come rcio-do-rio-de-janeiro

Miguez, P. (2007). Economia criativa: Uma discussão preliminar. In G. M. Nussbaumer (Ed.), Teorias e políticas da cultura: Visóes multidisciplinares (pp. 95-113). Salvador: EDUFBA.

MPF (2018). A Lava Jato em números no Rio de Janeiro. http://www.mpf.mp.br/para-o-cidadao/caso-lava-jato/atuacao-na-1a-instancia/rio-de-j aneiro/resultados

Nogueira, I. (2019). Não cabe mais político carnavalesco, diz Crivella. https://www.folhape.com.br/politica/politica/rio-de-janeiro/2019/03/03/NWS,97932,7, 1281,POLITICA,2193-NAO-CABE-MAIS-POLITICO-CARNAVALESCO-DIZ-CRIV ELLA.aspx

Odilla, F. (2018). Em posts e projetos de lei: Pelo que lutava Marielle Franco, vereadora assassinada no Rio. http://www.bbc.com/portuguese/brasil-43398816

Reis, A. C. (2008). Introdução. In A. C. Reis (Ed.) Economia criativa como estratégia de desenvolvimento: Uma visão dos países em desenvolvimento (pp. 14-49). São Paulo: Itaú Cultural.

Silveira, D. (2019). Confiança da indústria do RJ atinge o maior índice em 8 anos, diz Firjan.

https:/g1.globo.com/rj/rio-de-janeiro/noticia/2019/01/30/confianca-da-industria-do-rj -atinge-o-maior-indice-em-8-anos-diz-firjan.ghtml

Soares, V. (2018). O corte na inovação e as consequências para o país. https://www.segs.com.br/mais/economia/118239-o-corte-na-inovacao-e-as-consequen cias-para-o-pais

Teixeira, P. (2019). Descompromisso do governo quanto às reformas causa frustração. https://jornal.usp.br/atualidades/descompromisso-do-governo-quanto-as-reformas-ca usa-frustracao

Tomaz, P. C. (2010). A preservação do Patrimônio Cultural e sua trajetória no Brasil. Fênix: Revista de História e Estudos Culturais, 7, 1-12.

Johnson, E., \& Fredman, O. (2018). 2018 City RepTrak ${ }^{\circledR}$ the Most Reputable Cities in the World.

https://www.reputationinstitute.com/sites/default/files/pdfs/2018-City-RepTrak.pdf

Veja Rio (2016). Pesquisa revela que 71\% dos cariocas estão insatisfeitos com a cidade. https://vejario.abril.com.br/cidades/pesquisa-revela-que-71-dos-cariocas-esta-insatisfei to-com-a-cidade

Venturelli, S. (2000). From the Information Economy to the Creative Economy: Moving Culture to the Center of International Public Policy. Washington DC: Center for Arts and Culture. 